\title{
Impact of Covid-19 on MSMES in India and Strategies for Revival of MSMES Post Covid-19
}

\author{
Dr. Y. Arundhathi, Associate Professor And Hod , S.V Arts College, Tirupati.
}

\begin{abstract}
Today the entire world is under the grip of COVID19. It is impacting the global economy and creating atmosphere of uncertainty. This Pandemic has not spared any sector such as agriculture, corporate, medium and small industry and services sector. MSMEs are the backbone of the Indian economy was hit due to demonetization and GST implementation. In India COVID19 has battered all sectors of the economy MSMEs are the worst hit. MSMES are considered as a growth engine of the nation and they contribute $33.5 \%$ of India's manufacturing output, and giving employment to 121 million people and generation $45 \%$ of India's exports. In this paper an attempt is made to identify the problems of MSMEs, and to study the impact of COVID19 on MSMEs. Another attempt is made to examine the measures taken by the government of India in MSMEs sectors to achieve the dream of self reliant India.
\end{abstract}

\section{INTRODUCTION}

The outbreak of COVID19 affected the economies across the world and businesses. After 100 years the world is facing the worst situation. This Pandemic has not spared any sector such as agriculture, corporate, medium and small industry and services sector. MSMEs are the backbone of the Indian economy was hit due to demonetization and GST implementation. Now they are recovering slowly and showing signs of improvement and contributing to growth rate. In India COVID19 has battered all sectors of the economy MSMEs are the worst hit. MSMES are considered as a growth engine of the nation and they contribute $33.5 \%$ of India's manufacturing output, and giving employment to 121 million people and generating $45 \%$ of India's exports. Majority of MSMES relies on day -to-day business. Due to lockdown and decrease in demand MSMEs faced the most vulnerable situations. According to survey conducted by All India Manufacturers Organization (AIMO) covering 5000 MSMEs has revealed that $71 \%$ of MSMEs were not able to pay salaries in March. The survey also reveals that $43 \%$ of MSMEs will be closed down if the panic exceeds beyond 8 weeks. Large number of MSMES will be choked and heading towards permanent closer. Credit deficit, shortage of working capital and decreasing demand for non- essential commodities hit the MSMEs. In this paper an attempt is made to analyze the COVID19 impact on MSMEs during lockdown period, and a critical evaluation of Government of India policies in lifting the MSMEs during the lock down and post lockdown period.

\section{$>$ Significance of MSMEs:}

- MSMEs are the second largest employment provider in India

- At present there are nearly 56 million enterprises providing employment to approximately 124 million people in India. Among them 14 percent are women led enterprises and 60 percent are in rural based enterprises.

- MSMEs account for 46 percent of exports and contribute to 8 percent of GDP.

- MSMEs are the growth engines of the nation. Investing on MSMEs would have multiple benefits in boosting the economy such as increasing employment and solving the issues of migrating skilled and unskilled labour to rural areas to metro cities.

- MSMEs are the most dynamic sector providing employment opportunities in rural and semi urban and urban areas.

\section{$>$ Customers and changing demands:}

Indian MSMEs are traditional based and demand for commodities is limited for the domestic market. Increasing competition and evolving consumption have led need based demand. Therefore it is necessary to the MSMEs to design, manufacture and sell the product according to the needs of the customers. MSMEs have to be connected to the demand led environment and linked to the changing market dynamics through consumer oriented approaches.

\section{Credit Availability to MSMEs:}

The following table shows the credit deployment by the banks during Lock down period.

\section{* Credit Deployment by the Banks this Year in crores}

\begin{tabular}{|c|c|c|c|c|c|}
\hline Sector & March & April & May & June & 354,720 \\
\hline $\begin{array}{c}\text { Micro and } \\
\text { small }\end{array}$ & 381,824 & 358,340 & 353,000 & 352,690 & 101,990 \\
\hline Medium & 105,600 & 99,450 & 99,840 & 95,675 & $9,148,075$ \\
\hline $\begin{array}{c}\text { Gross Bank } \\
\text { credit }\end{array}$ & 9,263130 & $9,153,122$ & $9,108,880$ & $9,136,004$ & \\
\hline
\end{tabular}

Table 1

Source: Business Standard Internet. 
April was a washout with the severe lockdown effect. May was also marked by dull activity. June and July showed a small improvement in the performance of MSMEs. There is small growth in outstanding loans of micro and small enterprises 352,690 crores in June and 354720 crores in July. Medium size segment also showed an increase of 6,315 crores in July 2020.

MSMEs survival during post pandemic period:

The environment during post pandemic is totally different from what we are seeing today especially in the field of MSMEs. The following are the changes that we can expect in the MSME sector.

- In India out of 63 million MSMEs only 32 percent are engaged digitally and 68 percent are not adopting digital practices. In order to survive long run these business processes should engage digital practices. To adopt this practice it is very difficult for the MSMEs. But without digitize the MSMEs cannot survive in post pandemic period as people will continue to avoid social gathering and maintaining social distancing.

- Working capital management should be given more emphasis. Fast collections from receivables will be useful to meet salaries and day to day expenses.

- To maintain working capital high credit support is needed.

- Environmental consciousness and sustainability is needed.

- More emphasis should be given on innovation. MSMEs cannot survive without innovation in post pandemic period.

- Training should be given to the staff towards digital practices. So that they can perform variety of roles in post pandemic period.

\section{Relief measures Announced by the Government of India for MSMEs:}

Government of India heading towards self reliant economy and announces 20 lakh crores economic packages on 12.5.2020. It is around 10 percent of GDP.

- Economy will bring quantum jumps rather than incremental changes.

- The cycle of demand supply which require each stakeholders of the supply chain to be active.

- GOI proposed a technology driven system in the $21^{\text {st }}$ century with good financial support.

- GOI aimed at modern Indians identity is only with appropriate infrastructure.

- Our vibrant demography is our strength.

\section{A. Collateral free loans:}

The Government of India guaranteed loans to the extent of Rs 3 lakhs. NBFEs and banks will offer up to 20 percent of credit as on February 29, 2020 to MSMEs. Units up to 100 crores turnover and 25 crores outstanding credit are eligible for taking these loans. They will have four year tenure with a moratorium of 12 months on principal payment. Interest rate $9.25 \%$ to $9.75 \%$ from banks. $100 \%$ credit guarantee cover to banks and NBFCs on principal. This scheme can be used up to 31, October 2020. Complete credit guarantee was given by the government to the lenders on principal and interest amount. To support this initiative SIDBI has a plan to create SPV to mobilize equity and debt funds. Those MSMEs which are paying regular repayments and those who are having outstanding loans will be able to avail this scheme.

\section{B. Subordinate debt:}

Provision of Rs. 20000 crore as a subordinate debt has been created for stressed MSMEs. Over 200000 MSMEs are likely to get this benefit. Those MSMEs which are NPA stressed will be given this benefit. Government will provide support of Rs. 4000 crore to CGTMSE. Banks are given by partial credit guarantee support from CGTMSE.

\section{Equity infusion for MSMEs:}

Equity infusion of Rs 50,000 crores for MSMEs are given through fund of funds. Those MSMEs with growth potential and viability will be provided with equity funding by the government. Fund of funds will be operated through mother fund and daughter funds. These measures will help the MSME size and capacity and encourages MSMEs to get listed in stock exchanges.

\section{Marketing and liquidity help:}

MSMEs are promoted with E-Market linkage. This facilitates the MSMEs to trade fairs and exhibitions. To generate data in $\mathrm{E}$ marketplace and to enhance transaction based lending Faintest will be used.

\section{E. Changing MSME definition:}

There is a proposal to increase the monetary limit in defining MSMEs. The distinction between the manufacturing and service sector to be eliminated. Rs 450 billion were given to MSMEs under collateral free loans in February 2020. Those MSMEs who are likely to face risk would benefit hugely from the Rs 200 billion subordinate loans announced for them. Recently the Government of India revised the definition of MSMEs. Old definition of MSMEs created a fear among business people. Because there is a limited scope to expand their business.

Criteria: Investment in plant \& machinery or equipment:

\begin{tabular}{|c|c|c|c|}
\hline Classification & Micro & Small & Medium \\
\hline $\begin{array}{c}\text { Manufacturing } \\
\text { enterprises }\end{array}$ & $\begin{array}{c}\text { Investment }<25 \\
\text { lakh }\end{array}$ & $\begin{array}{c}\text { Investment }<5 \\
\text { crore }\end{array}$ & $\begin{array}{c}\text { Investment }<10 \\
\text { crore }\end{array}$ \\
\hline Service & Investment & Investment $<$ & Investment $<5$ \\
enterprises & $<10$ lakh & 2 crore & crore \\
\hline
\end{tabular}

Table 2

Revised MSME Classification

Composite criteria: Investment and Annual Turnover

\begin{tabular}{|c|c|c|c|}
\hline Classification & Micro & Small & Medium \\
\hline Manufacturing & Investment & Investment $<$ & Investment $<$ \\
& $<1$ crore & 10 crore & 20 crore \\
\hline Service & turn over $<5$ & Turn over $<$ & Turn over \\
enterprises & crore & 50 crore & $<100$ crore \\
\hline
\end{tabular}

Table 3 
Government procurement tenders up to Rs 200 are disallowed in Global tenders. This is major step towards self reliant India and support to Make in India. This measure will help the MSMEs to increase their domestic business.

\section{CONCLUSIONS}

Every country in world is affected with pandemic. Most powerful economies in the world are in the grip of pandemic and the situation become helpless and uncontrollable. If we compare India with other countries we are in a better position. It is because of early lock down in India and creating awareness among people in social distancing and the severity of COVID19. From this pandemic India realized its potential. During lock down we have sufficient food grains in our country. Work from home digital practice are the challenges of future India. To ensure the survival and revival of MSMEs, they should focus on measures announced by the government in capital issues, maintaining the liquidity at all times, reducing fixed and variable costs and managing the cash flow. Good governance, reporting system and continuous monitoring of above variables will ensure MSMEs to outcome the COVID19 .If the steps taken by the government in true spirits, the MSMEs will be tremendously benefited and perform well in building the economy towards make in India. But it will depend on seriousness in implementation and monitoring by the government including states coordination and cooperation.

\section{REFERENCES}

[1]. http:// economic times. Indiatimes.cok/ topic/UN Department of economic and social affairs.

[2]. http://www. India briefing .com / news / social economic impact of covid 19 India

[3]. http ://www. India- briefing . com/ news/ micro-smallmedium- enterprises-India explainer- 17887.html

[4]. https://indianexpress. com/article/india/fm-nirmalasitharam-press-conference-liveupdates.covid-relief6407734.

[5]. https:indianexpress.com article/explained/nirmala seetharam-credit-guarantee to -msmes-6408533. 